\title{
A new species of Amblyseius Berlese (Acari, Phytoseiidae) from the state of Rio Grande do Sul, Brazil
}

\author{
Noeli Juarez Ferla ${ }^{1} \&$ Guilherme Liberato Silva ${ }^{1}$
} ${ }^{1}$ Museu de Ciências Naturais, Centro Universitário UNIVATES. Rua Avelino Tallini, 171. Caixa Postal 155, $95900-000$ Lajeado-RS, Brazil.
njferla@univates.br

\begin{abstract}
A new species of Amblyseius Berlese (Acari, Phytoseiidae) from the state of Rio Grande do Sul, Brazil. A new species of Amblyseius Berlese, A. vitis sp. nov. is described from Dois Lajeados, State of Rio Grande do Sul. The specimens were collected on Stachys arvensis L. (Lamiaceae) and Plantago tomentosa Lam. (Plantaginaceae).
\end{abstract}

KEYWORDS. Plantago tomentosa; predator; Stachys arvensis; Vitis labrusca; weed.

RESUMO. Uma nova espécie de Amblyseius Berlese (Acari, Phytoseiidae) do Rio Grande do Sul, Brasil. Uma nova espécie de Amblyseius Berlese é descrita para o estado do Rio Grande do Sul, no Sul do Brasil. Amblyseius vitis sp. nov. é descrita de Dois Lajeados, Rio Grande do Sul. Os espécimes foram coletados sobre Stachys arvensis L.(Lamiaceae) e Plantago tomentosa Lam. (Plantaginaceae).

PALAVRAS-CHAVE. Planta daninha; predador; Plantago tomentosa; Stachys arvensis; Vitis labrusca.

The Phytoseiid mites feed on spider mites, nematodes, fungal spores, pollen and exudate from plants and soil. Several species are utilized in biological control program (Moraes 2002). The species of Amblyseius Berlese are classified as generalist predators, since they use various types of foods, showing better reproductive rates in this type of feeding than those of tetranychid (McMurtry \& Croft 1997). Amblyseius chiapensis (Deleon, 1961), Amblyseius herbicolus (Chant 1959), Amblyseius operculatus (DeLeon, 1967) and Amblyseius saopaulus (Denmark \& Muma 1973) are the species of this genus reported from Rio Grande do Sul, Brazil (Ferla \& Moraes 1998, 2002; Lorenzato 1987, 1988; Ferla et al. 2005, 2007; Moraes et al. 2004). The new species herein described has been collected on a weed commonly found in grape orchards in Rio Grande do Sul, is described and illustrated.

\section{MATERIALAND METHODS}

The mites were collected from the leaves of Stachys arvensis L. (Lamiaceae) and Plantago tomentosa Lam. (Plantaginaceae) found in crop of grape Bordeaux variety (Vitis labrusca L.: Vitaceae). The specimens were mounted in Hoyer's medium on glass slides and observed under a binocular microscope. The slides were dried on a slide warming plate, ringed with nail polish. The morphological details were studied under a phase contrast microscope. The drawings were made using a camera lucida apparatus. The setal nomenclature is that of Rowell et al. (1978) and Chant \& Yoshida-Shaul (1992) for the dorsal and ventral surfaces of the idiosoma, respectively. Measurements are given in micrometers $(\mu \mathrm{m})$, with their range given in parentheses.

\section{Amblyseius vitis Ferla \& Silva sp. nov.} (Figs. 1-5)

Diagnosis. Amblyseius vitis sp. nov. is similar to Amblyseius waltersi (Schicha, 1981). However, the latter have setae s4, Z4, Z5, Sge e Sti IV longer 38, 20, 40, 37 e 34\%, respectively, than Amblyseius waltersi. The setae $\mathrm{j} 3$ are $33 \%$ shorter in the latter species. The setae J5, Z4 e Z5 serrated in A. waltersi are smooth in the new species.

Female. (Three specimens measured). Yellowish in life. Idiosomal setal pattern: 10A:9B/JV-3/ZV.

Dorsum (Fig. 1) - Dorsal shield smooth, 409 (380-425) long, 293(280-305) wide, j1 33 (28-38), j3 29 (28-30), j4 5(5), j5 5(5), j6 6(5-6), J2 6(5-8), J5 10 (10), z2 6 (5-8), z4 8 (8), z5 5 (5), Z1 7 (5-8), Z4 198 (188-208), Z5 428 (418-438), s4 188 (175-200), S2 9 (8-10), S4 9 (8-10), S5 9 (8-10), r3 12 (8-15), R1 7 (5-8). Setae r3 and R1 on interscutal membrane. All setae smooth.

Peritreme (Fig. 2) - Extending forward to level of j1.

Venter (Fig. 3) - All shields smooth. Sternal shield with three pairs of setae and two pairs of liryfissures; distances between St1-St3 74 (70-78), St2-St2 83 (80-85). Distance between St5-St5 88 (88). Ventrianal shield nearly pentagonal, with lateral margins slightly concave, 133 (123-145) long, 97 (95-98) wide at ZV2 level and 98 (90-105) wide at anus level, with three pairs of setae and one pair of preanal pores posterior and about in longitudinal line with seta JV2. Two pars of slender metapodal shields. Setae JV5 smooth: 106 (103-108).

Chelicera (Fig. 4) - Fixed digit 41(38-45) long, with eight to ten teeth. Movable digit 36 (34-40) long, with three teeth.

Spermatheca (Fig. 5) - Calyx in form of bell, 22 (20-23) long and 10 (10) diameter in median region; atrium nodular.

Legs (Fig. 6) - With setaceous macrosetae of the following lengths: Sge I 61 (55-65), Sge II 47 (43-50), Sge III 90 (88-93), Sti III 73 (70-75), Sg IV 207 (200-213), Sti IV 166 (163-170), St IV 129 (125-133). Chetotactic formula of genu II 2-2/0,2/0-1; genu III $1-2 / 1,2 / 0-1$.

Male - Unknown. 


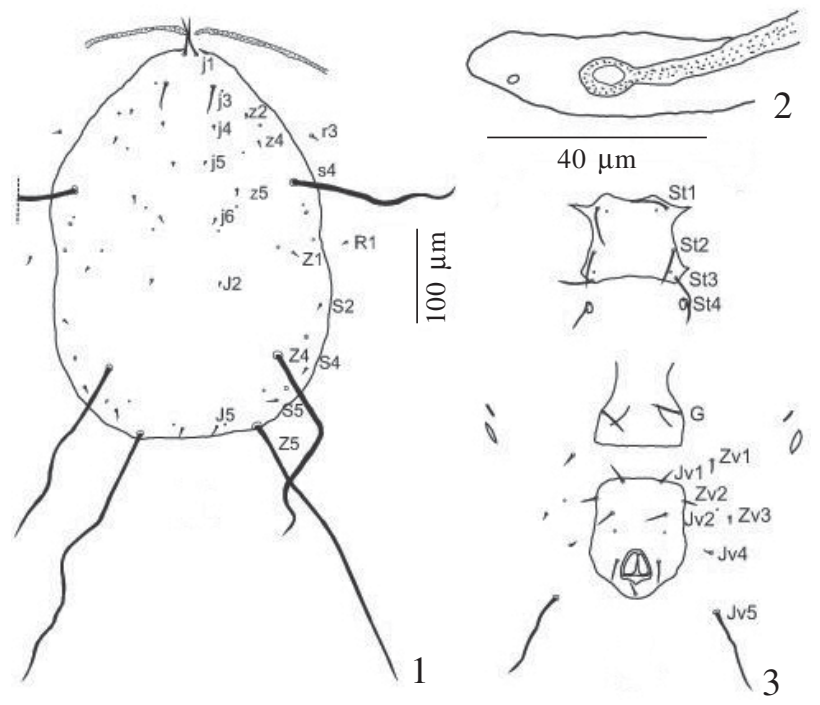

Figs. 1-3. Amblyseius vitis n. sp. - Female: 1. Dorsal shield, 2. Peritrema, 3. Ventral surface

Type Material. Holotype female. Dois Lajeados (altitude: 626 m, Posição: Latitude 28 56’29" S e 51 $51^{\circ} 44^{\prime \prime}$ W, Rio Grande do Sul, Brazil, 17/VII/2006, on Stachys arvensis L. (Lamiaceae). Two female paratype, same locality as holotype, 07/XI/2006, on Plantago tomentosa Lam. (Plantaginaceae). All the specimens have been collected by Guilherme Liberato da Silva. The type specimens are deposited at Departamento de Entomologia, Fitopatologia e Zoologia Agrícola, Escola Superior de Agricultura "Luiz de Queiroz" (ESALQ), Universidade de São Paulo (USP), Piracicaba - SP.

Comments. Amblyseius vitis sp. nov. belongs to the andersoni-group by having the spermatheca with calyx dish-, cup-, bell- or V-shaped, with the length/width ratio at the mid-point of the calyx <3.0:1.0 (Chant \& McMurtry 2004).

Etymology. The new species is named after the crop where the specimens were found.

Acknowledgement. We are thankful to Dr. G. J. de Moraes, Piracicaba, Brazil for checking the identity of the new species and comments on previous version of the manuscript. G. L. Silva is a fellowship of Museu de Ciências Naturais.

\section{REFERENCES}

Chant, D. A. 1959. Phytoseiid mites (Acarina: Phytoseiidae) . Part I. Bionomics of seven species in southeastern England. Part II. A taxonomic review of the family Phytoseiidae, with descriptions of thirty-eight new species. The Canadian Entomologist 12: 166 p.

Chant, D. A. \& J. A. McMurtry. 2004. A review of the subfamily Amblyseiinae Muma (Acari: Phytoseiidae): Part III. The tribe Amblyseiini Wainstein, subtribe Amblyseiina n. subtribe. International Journal of Acarology 30: 171-228.

Chant, D. A. \& E. Yoshida-Shaul. 1992. Adult idiosomal setal patterns in the family Phytoseiidae(Acari: Gamasida). International Journal of Acarology 18: 177-193.

Received 28/07/2008; accepted 17/06/2009

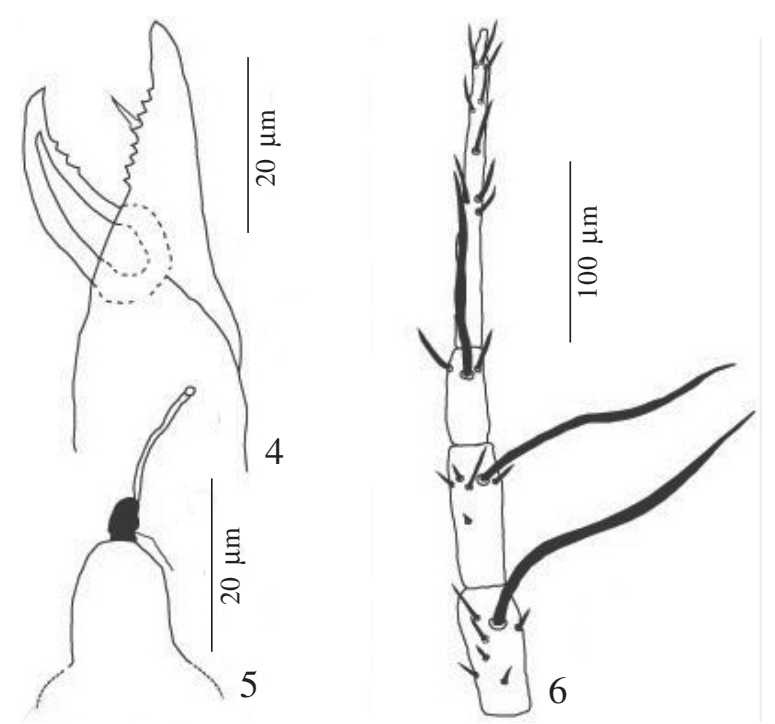

Figs. 4-6. Amblyseius vitis n. sp. - Female: 4. Chelicera, 5. Spermatheca, 6. Leg IV.

DeLeon, D. 1961. Eight new Amblyseius from México with collection notes on two other species (Acarina: Phytoseiidae). The Florida Entomologist 44: 85-91.

Deleon, D. 1967. Some mites of the Caribbean Area. Part I. Acarina on plants in Trinidad, West Indies. Lawrence, Alles Press Inc., 1-66 p.

Denmark, H. A. \& M. H. Muma. 1973. Phytoseiidae mites of Brazil. Revista Brasileira de Biologia 23: 235-276.

Ferla, N. J.; M. M. Marchetti \& J. C. Siebert. 2005. Acarofauna (Acari) de Erva Mate (Illex paraguariensis St. Hil.: Aqüifoliácea) no Estado do Rio Grande do Sul. Biociências 13: 133-142.

Ferla, N. J.; M. M. Marchetti \& D. Gonçalves. 2007. Ácaros predadores (Acari) associados à cultura do morango (Fragaria sp., Rosaceae) e plantas próximas no Estado do Rio Grande do Sul. Biota Neotropica 7: $1-8$.

Ferla, N. J. \& G. J. de Moraes. 1998. Ácaros predadores em pomares de maçã no Rio Grande do Sul. Anais da Sociedade Entomológica do Brasil 27: 649-654.

Ferla, N. J. \& G. J. de Moraes. 2002. Ácaros predadores (Acari) em plantas nativas e cultivadas do Estado do Rio Grande do Sul, Brasil. Revista Brasileira de Zoologia 19: 1011-1031.

Lorenzato, D. 1987. Controle biológico de ácaros fitófagos na cultura da macieira no município de Farropilha, RS. Agronomia Sulriograndense 20: 167-183.

Lorenzato, D. 1988. Ocorrência e controle biológico de ácaros fitófagos em fruteiras rosáceas. IPAGRO Informa 31: 93-96.

McMurtry, J. A. \& A. B. Croft. 1997. Life-styles of Phytoseiidae mites and their roles in biological control. Annual Review Entomology 42: 291-321.

Moraes, G. J. de. 2002. Controle biológico de ácaros fitófagos com ácaros predadores, p. 225-237. In: J. R. Parra, P. S. M. Botelho, B. S. Corrêa-Ferreira \& J. M. S. Bento (eds.), Controle biológico no Brasil: Parasitóides e predadores. Barueri, Editora Manole Ltda., xxiii+609 p.

Moraes, G. J. de; J. A. McMurtry; H. A. Denmark \& C. B. Campos. 2004. A revised catalog of the mite family Phytoseiidae. Zootaxa 434: $1-494$.

Rowell, H. J.; D. A Chant \& R. I. C. Hansell. 1978. The determination of setal homologies and setal patterns on the dorsal shield in the family Phytoseiidae (Acarina: Mesostigmata). The Canadian Entomologist 110: 859-876.

Schicha, E. 1981. Five known and five new species of phytoseiid mite from Australia and the South Pacific. General and Applied Entomology 13: 29-46. 